\title{
Focal Cerebral Magnetic Resonance Changes Associated with Partial Status Epilepticus
}

\author{
*Thomas R. Henry, *Ivo Drury, *†James A. Brunberg, *Page B. Pennell, \\ $\ddagger$ Paul E. McKeever, and *Ahmad Beydoun \\ ${ }^{*}$ Department of Neurology and Divisions of $\dagger$ Neuroradiology and $\ddagger$ Neuropathology, University of Michigan Medical \\ Center, Ann Arbor, Michigan, U.S.A.
}

Summary: We report 2 patients with transient abnormalities on magnetic resonance imaging (MRI) associated with partial status epilepticus (SE). A man with a 4-month history of partial seizures had complex partial SE for 9 days, with left temporal maximum on ictal EEG. Left temporal lobe $T_{2}$ signal was increased on MRI during $S E$, but cerebral MRI was normal 9 weeks later. A woman with "cryptogenic" temporal lobe epilepsy for 16 years had complex partial SE for 1 week, with right temporal maximum on ictal EEG. $T_{2}$ Signal was increased over the entire right temporal lobe, extending into the insula, without mass effect, on MRI 1 month after SE ended. Repeat
MRI 1 month later showed marked decrease in volume of increased $T_{2}$ intensity, without gadolinium enhancement, but with mild mass effect over the right anteroinferomesial temporal areas. A gemistocytic astrocytoma was resected. Focal cerebral MRI abnormalities consistent with cerebral edema may be due to partial SE but also may indicate underlying glioma, even in long-standing partial epilepsy. Focal structural imaging changes consistent with neoplasm should be followed to full resolution after partial SE, Key Words: Magnetic resonance imagingStatus epilepticus-Partial epilepsy-Cerebral edemaAstrocytoma.
Partial epilepsy has been associated with transient focal cerebral abnormalities on cerebral $x$-ray computed tomography $(\mathrm{CT})$ in $>60$ reported cases (Rumack et al., 1980; Dillon et al., 1984; Rougier et al., 1984; Jayakumar et al., 1985; Sammaritano et al., 1985; Sethi et al., 1985; Zegers de Beyl et al., 1985; Goulatia et al., 1987; Bansal et al., 1989) and on cerebral magnetic resonance imaging (MRI) in three cases (Kramer et al., 1987; Riela et al., 1991; Takamatsu et al., 1991). In many of these cases, the abnormalities appeared after occurrence of documented partial status epilepticus (SE). Most of these reports suggest focal cerebral edema as the basis of these transient neuroimaging abnormalities. We report 2 patients who developed transient focal hyperintensity on MRI after partial SE, 1 of whom was shown to have an astrocytoma.

Received November 1992; revision accepted January 1993 Address correspondence and reprint requests to Dr. T. R. Henry at Department of Neurology, University of Michigan Hospital, 1B300/0036, 1500 E. Medical Center Dr., Ann Arbor, MI 48109-0036, U.S.A.

\section{CASE REPORTS}

\section{Case 1}

A 41-year-old, right-handed diabetic man had a 4-month history of untreated complex partial seizures (CPS) characterized by an aura of a foul smell, after which he acted in a confused manner and sometimes stared unresponsively for $<1 \mathrm{~min}$. A generalized tonic-clonic seizure (GTC) was treated with $1 \mathrm{~g}$ phenytoin (PHT) intravenously (i.v.). After the GTC, the patient remained persistently confused, with severe expressive and mild receptive aphasia. A noncontrast cerebral CT scan performed that day was normal. During a 30-min EEG performed on the next day, four partial seizures of left temporal maximal electrographic activity were recorded. PHT was administered incrementally. A repeat brain CT with and without contrast infusion was normal 2 days after the GTC. Lumbar puncture yielded clear, colorless fluid with a protein level of $0.67 \mathrm{~g} / \mathrm{L}$, normal cell count, normal glucose, normal IgG index, and no oligoclonal bands; bacterial, fungal and tuberculous cultures were negative. Bilat- 
eral carotid angiography was normal. MRI performed 7 days after the GTC showed an area of decreased signal intensity on $\mathrm{T}_{1}$ images (not becoming enhanced with gadolinium) and increased signal intensity on proton density and and $T_{2}$ images over gray and white matter of the left temporal lobe, without mass effect (Fig. 1). The confusion and receptive aphasia resolved fully 9 days after the GTC.

The patient was subsequently referred to the University of Michigan Medical Center with a diagnosis of probable brain tumor. A repeat MRI performed 10 weeks after the GTC was normal (Fig. 2). At that time examination showed an alert and oriented man with a residual mild expressive aphasia and a right extensor plantar response. Neurologic examination was normal 1 month later. He continued to have one to two CPS a month that had the same semiology as those that occurred before SE, despite increasing doses of carbamazepine (CBZ) for the next year.

\section{Case 2}

A 24-year-old right-handed woman who had had CPS for 16 years demonstrated a right temporal MRI abnormality after partial SE during the peripartum period. The patient's partial seizures began at age 8 years, with paroxysmal dizziness followed by staring and loss of awareness. No etiology or predisposing factors for partial epilepsy was identified early in the illness. In several years, the aura evolved into epigastric discomfort, often associated with feelings of unreality. Interictal EEGs during the 1970s showed right frontotemporal spikes; cerebral CT scan in 1979 was normal. She was treated subsequently with phenobarbital (PB), primidone, phensuximide, PHT, CBZ, and valproate in various combinations. Her best seizure control was obtained with CBZ and PB; she had one CPS a month in 1985 and 1986. An interictal EEG in 1986 showed rare right frontotemporal spikes, frequent right temporal delta transients, and rare left temporal delta transients.

By 1987, the frequency of CPS had increased to 3 a month. Neurologic examination remained normal. Neuropsychometric testing showed a Wechsler Adult Intelligence Scale-Revised full-scale IQ of 83, verbal IQ of 86 , performance IQ of 81 , and a Wechsler Memory Quotient of 91, but marked impairment of visuo-spatial delayed recall, consistent with dysfunction of the nondominant temporal lobe. An interictal EEG showed frequent right midposterior temporal sharp waves and delta transients, with rare left mid-temporal spikes. Cerebral MRI showed normal anatomic volumes but slightly increased signal intensity over the right hippocampus on proton density- and $T_{2}$-weighted images in 1987.

In the first 6 months of her second pregnancy in 1988 , the frequency of the patient's CPS increased. In the seventh month of pregnancy, she exhibited bizarre personality changes and rapidly fluctuating lethargy for 1 week. Neurologic examination showed intermittent unresponsiveness for 1 minute every 5-10 min, with left homonymous hemianopia and left fasciosomatic paresis during responsive periods. EEG later that day showed right temporal partial seizures as frequently as every $3-4 \mathrm{~min}$. Partial SE was controlled first by PHT and then by PHT plus PB for 2 days. Cerebral CT without contrast was again normal. She delivered twins 3 days after termination of SE. Immediately postpartum,
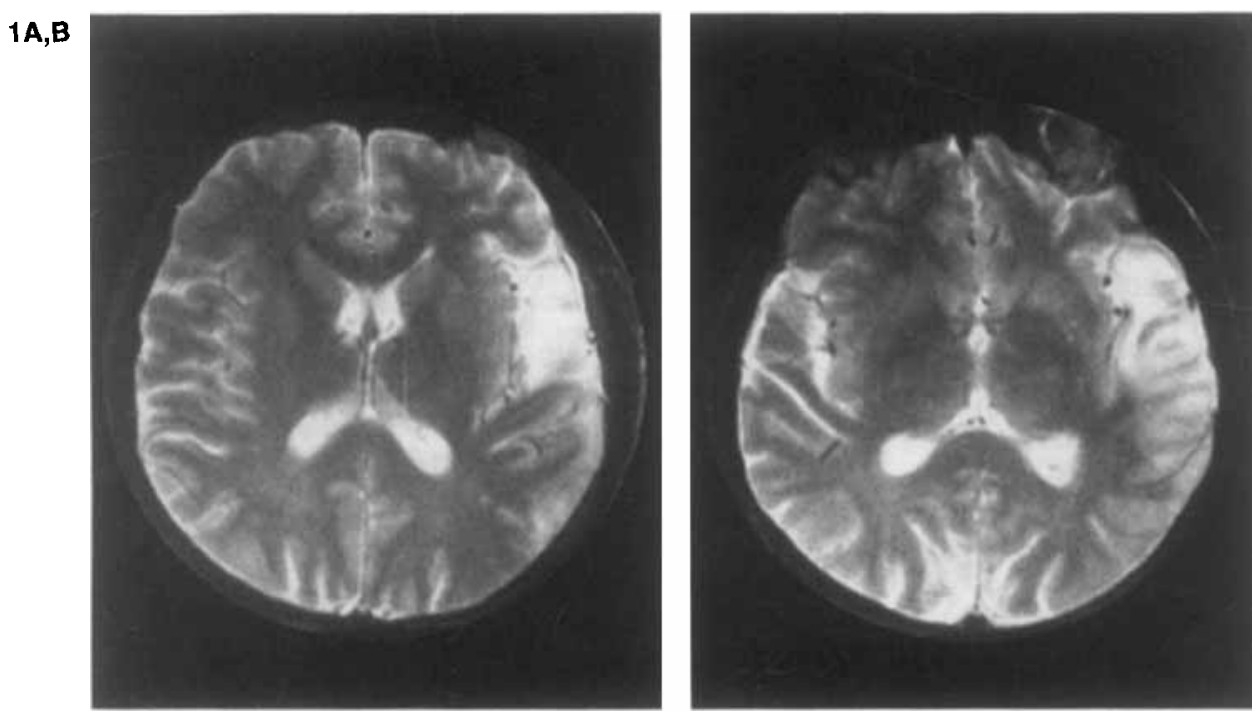

FIG. 1. Case 1. Magnetic resonance imaging (MRI) scans 1 week after onset of status epilepticus. $T_{2}$-weighted images (A and $B$ ) show increased left temporal gray and white matter signal intensity, without mass effect. These axial images were produced with a $0.35-T$ Diasonics system with spin-echo sequences of $T R=2,500$ and $T E$ $=90 \mathrm{~ms}$. The patient's left appears on the right of the image in Figs. 1-4. 
FIG. 2. Case 1. Magnetic resonance imaging (MRI) scans 9 weeks after termination of status epilepticus. Image planes are similar to those shown in Fig. 1 , but exhibit normal cerebral signal intensity. These $\mathrm{T}_{2}$ weighted images were produced with a 1.5-T GE Signa system with spin-echo sequences of TR $=3,000$ and $T E$ $=80 \mathrm{~ms}$.
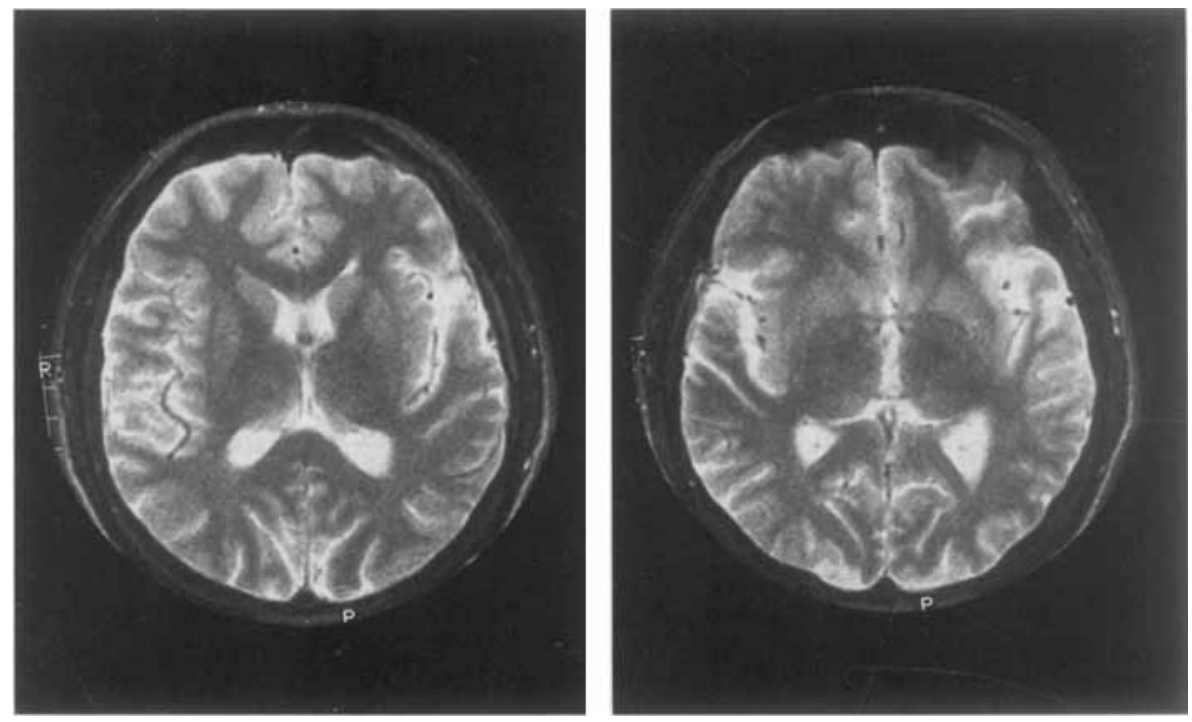

she had a left superior quadrantanopsia and a left pronator drift with an otherwise normal neurologic examination.

One week after termination of SE, MRI showed a large area of decreased signal intensity on $T_{1}$ weighted images and increased signal intensity on proton density- and $\mathrm{T}_{2}$-weighted images, particularly involving gray matter, over the entire right temporal lobe and extending over the entire insula into the right dorsolateral frontal cortex, with no definite mass effect (Fig. 3). Follow-up MRI 2 weeks later showed resolution of the right posteroand superotemporal changes and of most of the right insular and frontal changes but continued to show increased signal intensity on $\mathrm{T}_{2}$ images over gray and white matter in the lateral and mesial portions of the inferior right temporal lobe anteriorly, again without definite mass effect. Four weeks after the first postpartum scan, MRI showed decreased signal intensity on $T_{1}$ images (not becoming enhanced with gadolinium) of gray and white matter of the right infero- and mesiotemporal lobe anteriorly, associated with subtle mass effect, and unchanged distribution of increased signal intensity on proton density- and $\mathrm{T}_{2}$-weighted images as compared with the scan made 2 weeks earlier (Fig. 4). CPS per-

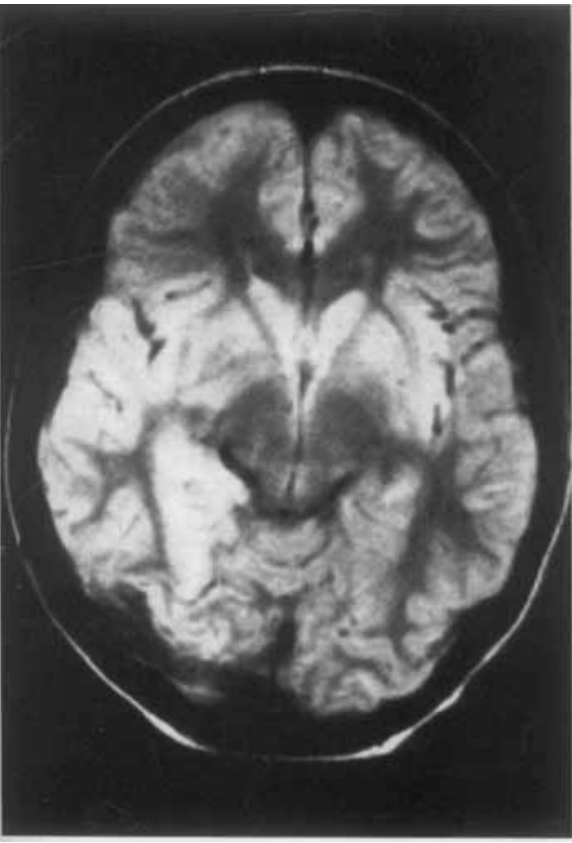

FIG. 3. Case 2. Magnetic resonance imaging (MRI) scans 1 week after termination of status epilepticus. Axial $\mathrm{T}_{2}$-weighted images demonstrate increased signal intensity throughout gray and white matter of inferior aspect of right temporal lobe. These images were produced with a 0.35-T Diasonics system with spin-echo sequences of TR $=2,000$ and $\mathrm{TE}=60 \mathrm{~ms}$. 
sisted (3-5/week) despite increasing PHT and PB levels. Right anterotemporal lobectomy was performed. A grade II astrocytoma with gemistocytes and giant cells was noted in inferomesial portions of the specimen; the remainder of resected neocortex and subcortical white matter was histologically normal. Postoperative cerebral radiation therapy was $5,580 \mathrm{rad}$. No new neurologic deficits were noted after lobectomy and irradiation.

With PHT monotherapy, the patient has remained free of her previous auras and CPS for 4 years after lobectomy. Neuropsychological testing 1 year after lobectomy showed no new deficits, with no change in memory performance from $1987 \mathrm{lev}$ els. Follow-up cerebral MRI and CT scans have shown no evidence of tumor recurrence.

\section{DISCUSSION}

Transient cerebral abnormalities on x-ray CT after partial SE were first reported by Rumack et al. (1980). Similar findings, consisting of focal white matter hypodensity, focal enhancement after contrast administration, absence of mass effect, and subsequent resolution of the SE-associated CT abnormalities have been described repeatedly (Dillon et al., 1984; Rougier et al., 1984; Sammaritano et al., 1985; Sethi et al., 1985; Zegers de Beyl et al., 1985; Jayakumar et al., 1985; Goulatia et al., 1987). Many of the $\sim 60$ reported cases of transient focal CT abnormalities were not clearly associated with partial SE, particularly in patients in India (Bansal et al., 1989). Of these patients, 5 underwent stereotaxic biopsy under CT guidance because of suspected brain tumor. The results showed normal brain tissue in 2 (Rougier et al., 1984; Zegers de
Beyl et al., 1985) and mild gliosis in 3 (Rougier et al., 1984). A conservative approach has thus been advocated when these radiographic findings are noted after partial SE (Rumack et al., 1980; Sammaritano et al. 1985; Zegers de Beyl et al., 1985; Kramer et al., 1987; Riela et al., 1991) and even in the absence of partial SE in partial epilepsy (Bansal et al., 1989).

Our first patient demonstrated temporal lobe gray and white matter MRI changes during a prolonged episode of confusion resulting from complex partial SE. Cerebral MRI was normal 9 weeks later. Three patients with transitory focal MRI abnormality after partial SE were reported previously (Kramer et al., 1987; Riela et al., 1991; Takamatsu et al., 1991). Two other patients reported to have focal cerebral MRI abnormality associated with partial SE did not undergo poststatus MRI to demonstrate resolution of the abnormality. In one of the 2 patients, anterotemporal lobectomy demonstrated only gliosis of resected tissue (Stone et al., 1986); in the other, MRI had been normal before SE (Bauer et al., 1989). In these 5 cases and in our first case, the MRI abnormality involved a focal area either of white matter or of white and gray matter combined, demonstrating decreased signal intensity on $\mathrm{T}_{1^{-}}$ weighted and/or increased signal intensity on $\mathrm{T}_{2^{-}}$ weighted images, without mass effect. In 1 , slight gadolinium enhancement of cortex adjacent to focal white matter changes was observed (Bauer et al., 1989). In all cases, partial SE lasted from 5 days to 2 weeks before obtainment of the MRI showing focal abnormality. In 4 of these 6 patients, the MRI scans demonstrating resolution of SE-associated changes had been performed as early as 1 month and as late as 9 months after termination of SE.
FIG. 4. Case 2. Magnetic resonance imaging (MRI) scans 5 weeks after termination of status epilepticus. Axial $T_{2}$ images demonstrate increased signal intensity confined to a smaller region of inferior aspect of right temporal lobe with relative sparing of cortex. These images were produced with a 1.5-T GE Signa system with spin-echo sequences of $T_{2}=3,000$ and $T E$ $=90 \mathrm{~ms}$.
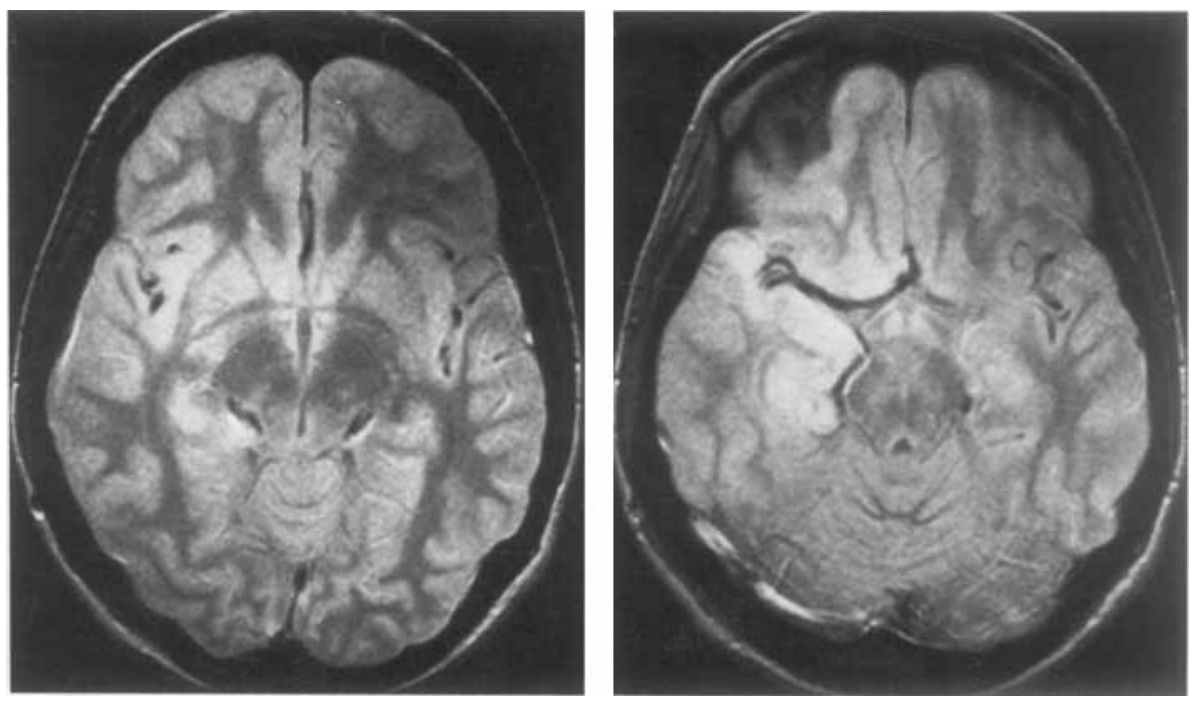
Our second patient had a long-standing history of CPS and a documented episode of partial SE. The first MRI after partial SE showed large areas of signal abnormality that had resolved partially 2 weeks later. Owing to findings consistent with hippocampal sclerosis (Kuzniecky et al., 1987; Berkovic et al., 1991) on the pre-SE MRI study, the new post-SE MRI changes were initially suspected to represent transient white matter edema resulting from partial SE. The cardinal features in the evolution of post-SE imaging in this patient were persistence of a relatively large area of signal abnormality (within a larger area of resolved abnormality), significant extrahippocampal gray matter changes, and subtle mass effect evident on later scanning. Because of these features, an anterotemporal lobectomy was performed; it showed a grade II astrocytoma.

The CT and MRI findings typical of focal cerebral edema in humans (Bradley, 1987; Clasen, 1990; Grossman, 1990) have not been described after a single partial seizure in the absence of other insults independently associated with cerebral edema. Recent reports of single photon emission CT after radionuclide injection during or soon after a single partial seizure indicate transitory regional hyperperfusion in areas of maximal ictal activity (Lee et al., 1988; Rowe et al., 1989). Earlier nontomographic scintiangiographic and contrast angiographic studies performed during or soon after SE or frequent partial seizures showed hemispheric hyperperfusion on the epileptogenic side (Prensky et al., 1973; Holmquest and Launey, 1974; Yarnell et al., 1974); in some of these cases, the angiographic abnormalities persisted for several days after the last seizure, but resolved eventually in all cases. Regional hyperperfusion and increased vascular permeability accompany single partial seizures in experimental models, but perfusion and vascular permeability increase in proportion to seizure frequency and duration (Lorenzo et al, 1972; Wasterlain, 1974; Petito et al., 1976; Nitsh and Klatzo, 1983; Loiseau et al., 1990). Increased vascular permeability causes vasogenic cerebral edema confined to cerebral white matter (Fishman, 1975). Thus, CT and MRI findings in many cases of partial SE may be attributable to vasogenic cerebral edema. Patients who have combined gray and white matter imaging abnormalities after partial SE presumably also have cytotoxic cerebral edema owing to regional ischemia or other cellular metabolic disturbances. Experimental models of SE demonstrate several possible pathophysiologic bases for cytotoxic cerebral edema (Delgado-Escueta et al., 1983). Cytotoxic cerebral edema associated with mitochondrial dysfunction may be the basis of the multifocal and predominantly gray matter neuroimaging abnormalities that can occur transiently after $\mathrm{SE}$ in the syndrome of mitochondrial myopathy, encephalopathy, lactic acidosis, and strokelike episodes (MELAS) (Yamamoto et al., 1984; Matthews et al., 1991).

The timing of development of MRI changes consistent with focal edema after partial SE is not well established. The focal MRI abnormality appears $\leqslant 5$ days after onset of partial SE and can resolve fully $\leqslant 4$ weeks after termination of SE. Our second case stresses the importance of following focal neuroimaging abnormalities associated with partial SE to complete resolution, because incomplete resolution of such abnormalities may be associated with an underlying neoplasm.

Acknowledgment: We thank Sally Mouilleseaux for assistance in manuscript preparation.

\section{REFERENCES}

Bansal BC, Dua A, Gupta R, Gupta MS. Appearing and disappearing CT scan abnormalities in epilepsy in India-an enigma. J Neurol Neurosurg Psychiatry 1989;52:1185-7.

Bauer J, Stefan H, Huk WJ, et al. CT, MRI and SPECT neuroimaging in status epilepticus with simple partial and complex partial seizures: case report. J Neurol 1989;236:296-9.

Berkovic SF, Andermann F, Olivier A, et al. Hippocampal sclerosis in temporal lobe epilepsy demonstrated by magnetic resonance imaging. Ann Neurol 1991;29:175-82.

Bradley WG Jr. Pathophysiologic correlates of signal alterations. In: Brant-Zawadzki M, Normal D, eds. Magnetic resonance imaging of the central nervous system. New York: Raven Press, 1987:23-42.

Clasen RA. Magnetic resonance imaging of human cerebral edema. In: Long DM, ed. Brain edema: pathogenesis, imaging and therapy. New York: Raven Press, 1990:491-509. (Advances in neurology; vol. 52.)

Delgado-Escueta AV, Wasterlain CG, Treiman DM, Porter RJ, eds. Status epilepticus: mechanisms of brain damage and treatment. New York: Raven Press, 1983. (Advances in neurology; vol. 34.)

Dillon W, Brant-Zawadzki M, Sherry RG. Transient computed tomographic abnormalities after focal seizures. Am J Nucl Radiat 1984;5:107-9.

Fishman RA. Brain edema. $N$ Engl J Med 1975;293:706-11.

Goulatia RK, Verma A, Mishra NK, Ahiya GK. Disappearing CT lesions in epilepsy. Epilepsia 1987;28:523-7.

Grossman CB. Magnetic resonance imaging and computed tomography of the head and spine. Baltimore: Williams \& Wilkins, 1990.

Holmquest DL, Launey WS. Abnormal scintiangiographic findings associated with seizure activity. Radiology 1974;111: $147-50$.

Jayakumar PN, Taly AB, Mohan PK. Transient computerized tomographic abnormalities following partial seizures. Acta Neurol Scand 1985;72:26-9.

Kramer RE, Lüders H, Lesser RP, et al. Transient focal abnormalities of neuroimaging studies during focal status epilepticus. Epilepsia 1987;28:528-32. 
Kuzniecky R, DeLa Sayette V, Ethier R, et al. Magnetic resonance imaging in temporal lobe epilepsy: pathologic correlations. Ann Neurol 1987;22:341-7.

Lee BI, Markand ON, Wellman HN, et al. HIPDM-SPECT in patients with medically intractable complex partial seizures. Ictal study. Arch Neurol 1988;45:397-402.

Loiseau H, Averet N, Arrigoni E, Cohadon F. Relation between epileptic activities and edema formation after cryogenic injury in the rabbit. In: Long DM, ed. Brain edema: pathogenesis, imaging and therapy. New York: Raven Press, 1990: 257-67. (Advances in neurology; vol. 52.)

Lorenzo AV, Shirahige I, Liang M, Barlow CF. Temporary alteration of cerebrovascular permeability to plasma protein during drug-induced seizures. Am J Physiol 1972;223:268-77.

Matthews PM, Tampein D, Berkovic SF, et al. Magnetic resonance imaging shows specific abnormalities in the MELAS syndrome. Neurology 1991;41:1043-6.

Nitsch C, Klatzo I. Regional patterns of blood-brain barrier breakdown during epileptiform seizures induced by various convulsive agents. J Neurol Sci 1983;59:305-22.

Petito CK, Schaefer JA, Plum F. The blood-brain barrier in experimental seizures. In: Pappius HM, Feindel W, eds. Dynamics of brain edema. Berlin: Springer-Verlag, 1976:38-42.

Prensky AL, Swisher CN, DeVivo DC. Positive brain scans in children with idiopathic focal epileptic seizures. Neurology 1973;23:798-807.

Riela AR, Sires BP, Penry JK. Transient magnetic resonance imaging abnormalities during partial status epilepticus. $J$ Child Neurol 1991;6:143-5.

Rougier A, Loiseau P, Rivel J, Cohadon F, Orgogozo JM. Partial epileptic seizures in four adolescents with abnormal CT scan, focal gliosis and spontaneous regression. Rev Neurol 1984; 140:171-8.

Rowe CC, Berkovic SF, Sia STB, et al. Localization of epileptic foci with postictal single photon emission computed tomography. Ann Neurol 1989:26:660-8.

Rumack CM, Guggenheim MA, Fasules JW, Burdick D. Transient positive postictal computed tomographic scan. J Pediatr 1980;97:263-4.

Sammaritano M, Andermann FA, Melanson D, et al. Prolonged focal cerebral edema associated with partial status epilepticus. Epilepsia 1985;26:334-5.

Sethi PK, Kumar BR, Madan VS, Mohan V. Appearing and disappearing CT scan abnormalities and seizures. $J$ Neurol Neurosurg Psychiatry 1985;48:866-9.

Stone JL, Hughes JR, Barr A, Tan W, Russell E, Crowell RM. Neuroradiological and electroencephalographic features in a case of temporal lobe status epilepticus. Neurosurgery 1986; $18: 212-6$.

Takamatsu K, Takizawa T, Sato S, et al. Transient focal abnormalities of MRI and angiographic neuroimaging in status epilepticus: case report. No To Shinkei 1991;43:289-94.

Wasterlain CG. Mortality and morbidity from serial seizures. Epilepsia 1974;15;155-76.

Yamamoto T, Beppu H, Tsubaki T. Mitochondrial encephalomyopathy: fluctuating symptoms and CT. Neurology 1984; 34:1456-60.

Yarncll PR, Burdick D, Sanders B, Stears J. Focal seizures, early veins, and increased flow. Neurology 1974;512-6.

Zegers De Beyl D, Hermanus N, Colle H, Goldman S. Focal seizures with reversible hypodensity on the CT scan. $J \mathrm{Neu}$ rol Neurosurg Psychiatry 1985;48:187-8.

\section{RÉSUMÉ}

Les auteurs rapportent 2 cas d'anomalies passageres de l'imagerie par resonnance magnetique (IRM) associees avec un état de mal epileptique (EME) partiel. Un homme ayant des attaques epileptiques partielles depuis quatre mois, a souffert d'un EME partiel complexe pour une durée de 9 jours, originaire du lobe temporal gauche sur l'electroencephalogramme. Durant l'EME, l'IRM a mis en evidence une augmentation du signal $\mathrm{T}_{2}$ au niveau du lobe temporal gauche, mais l'IRM devint normal 9 semaines plus tard. Une femme qui depuis 16 ans avait une epilepsie du lobe temporal a souffert d'un EME complex partiel pour une durée d'une semaine, originaire du lobe temporal droit sur l'electro-encephalogramme. Un mois plus tard, l'IRM a documente une augmentation du signal $T_{2}$ couvrant tout le lobe temporal droit ainsi que le lobe insulaire sans effet de masse. Un mois plus tard, l'IRM a demontre une reduction du signal $\mathrm{T}_{2}$, ainsi q'une absence d'intensification avec le gadolinium mais avec un peu d'effet de masse sur l'aspect anteroinferomesial du lobe temporal droit. Un astrocytome gemistocytique fut resecte.

Des anomalies cerebrales focales par l'IRM ressemblant l'oedeme cerebral peuvent être due a un EME focal, mais peuvent aussi indiquer une tumeur même si le patient souffre d'une epilepsie partielle de longue durée. Les anomalies radiologiques focales pouvant étre du a une tumeur doivent etre suivies jusqu'à ce qu'elles disparaissent entierement après un episode d'EME partial.

(Translation supplied by authors)

\section{RESUMEN}

Se presentan 2 pacientes en los que se detectaron abnormalidades transitorias en las imágenes de resonancia magnética (RM) asociadas con el "status epilepticus" (SE). Un hombre con una historia de 4 meses de epilepsia parcial padeció un SE parcial complejo durante 9 días, con un máximo en el EEG ictal en el area temporal izquierda. La señal $\mathrm{T}_{2}$ en la RM del area temporal izquierda se encontró incrementada durante el SE, pero el RM cerebral fué normal 9 semanas más tarde. Una mujer con historia de 16 años de epilepsia "criptogénica" del lóbulo temporal tuvo un SE parcial complejo durante una semana, con un máximo en el EEG ictal en la zona temporal derecha. La señal $T_{2}$ de la $R M$ se encontró incrementada en todo el lóbulo temporal derecho, extendiéndose a la ínsula, sin efecto de masa, un mes tras el término del SE. La RM fué repetida un mes más tarde, demostrando una reducción en el volumen del area de incremento en intensidad de la señal $T_{2}$, sin pronunciación con gadolinium, pero con un ligero efecto de masa sobre las areas anteroinferomesiales temporales derechas. Un astrocitoma gemistocítico fué reseccionado.

Las abnormalidades cerebrales focales en la RM compatibles con edema cerebral pueden ser debidas al SE parcial, pero también pudieran indicar la existencia de un glioma, incluso en casos con historias prolongadas de epilepsia parcial. Los cambios focales en las imágenes estructurales que aparecen durante SE, y que pudieran ser compatibles con neoplasmas, parecen necesitar seguimiento hasta su completa resolución.

(Translation supplied by authors)

\section{ZUSAMMENFASSUNG}

Wir berichten über zwei Patienten mit reversiblen abnormalen Befunden im Kernspin-Tomogramm (MRI) bei partiellem Status Epilepticus (SE). Ein Patient mit partieller Epilepsie über vier Monate war im complexen partiellen SE für neun Tage, mit links temporalem Maximum im iktalen EEG. Im linken Temporallappen fand sich abnormal hohe Signalintensität in $\mathrm{T}_{2}$-gewichteten Sequenzen $\left(\mathrm{T}_{2}-\mathrm{S}_{1}\right)$; neun Wochen später war das Cerebral-MRI normal. Eine Patientin mit Temporallappen-Epilepsie ungeklärter Ursache seit 16 Jahren hatte complexen partiellen SE für 
eine Woche, mit rechts temporalem Maximum im iktalen EEG, Einen Monat nach Ende des SE fand sich abnormal hohe T2-SI im gesamten rechten Temporallappen und in der Insula, jedoch ohne Massen-Effekt. Ein zweites MRI einen Monat darauf zeigte deutliche Reduktion in von abnormaler Signalintensität betroffener Hirnsubstanz und keine pathologische Anreicherung mit Gadolinium-DTPA, aber milden Massen-Effekt im rechten anteroinferomesialen Bereich. Ein gemistocytisches Astrozytom wurde reseziert.
Fokale abnormale Befunde im cerebralen MRI vereinbar mit Ödem können sowohl auf partiellen SE zurückzuführen sein, als auch auf ein zugrundeliegendes Gliom hinweisen, selbst nach langjähriger partiller Epilepsie. Fokale strukturelle pathologische Befunde im MRI nach partiellem SE vereinbar mit Neoplasie sollten Nachfolgeuntersuchungen erhalten bis volle Normalisierung bestätigt ist.

(Translation supplied by authors) 